\title{
Activation of NAD-dependent Lactate Dehydrogenase in Butyrivibrio fibrisolvens by Fructose 1,6-Diphosphate
}

\author{
By N. O. VAN GYLSWYK \\ South African Council for Scientific and Industrial Research-Onderstepoort Group \\ for Research on Digestion and Metabolism in Ruminants, National Chemical \\ Research Laboratory, P.O. Box 395, Pretoria, South Africa $000 \mathrm{I}$
}

(Received I November 1976)

INTRODUCTION

Joyner \& Baldwin (I966), Kistner \& Kotzé (1973) and M. J. Latham (personal communication) failed to find appreciable NAD-linked activity of lactate dehydrogenase (EC I.I.I.27) in extracts of Butyrivibrio fibrisolvens although $\left[\mathrm{I}^{-14} \mathrm{C}\right]$ pyruvate is converted to $\left[\mathrm{I}^{14} \mathrm{C}\right]$ lactate (van Gylswyk, I976). These results suggested that this bacterium might contain an unusual lactate dehydrogenase. The present work shows that the enzyme is similar to that of several other lactate-producing species, e.g. certain streptococci (Wolin, 1964) and Lactobacillus casei (de Vries et al., 1970), in that it is NAD-dependent and activated by fructose 1,6 -diphosphate.

\section{METHODS}

Bacterium and growth. The bacterium, isolate 12 , was the same as that used in a previous study (van Gylswyk, 1976). It was grown in medium containing ( $\left.\mathrm{g} \mathrm{l}^{-1}\right): \mathrm{K}_{2} \mathrm{HPO}_{4}, 0 \cdot 225$; $\mathrm{KH}_{2} \mathrm{PO}_{4}, 0.225 ; \mathrm{NaCl}, 0.45 ;\left(\mathrm{NH}_{4}\right)_{2} \mathrm{SO}_{4}, 0.45 ; \mathrm{CaCl}_{2}, 0.045 ; \mathrm{MgSO}_{4} .7 \mathrm{H}_{2} \mathrm{O}, 0.092 ; \mathrm{NaHCO}_{3}$, 6.37 ; cysteine. $\mathrm{HCl} . \mathrm{H}_{2} \mathrm{O}, 0.25 ; \mathrm{Na}_{2} \mathrm{~S} .9 \mathrm{H}_{2} \mathrm{O}, 0.25$; indigo carmine, 0.005; glucose, 9, rumen fluid (partly clarified by centrifuging at $12000 \mathrm{~g}$ for I h), $200 \mathrm{ml}$. Bacteria were harvested ( $12000 \mathrm{~g}, \mathrm{I} \mathrm{h}, 4^{\circ} \mathrm{C}$ ), and washed twice by resuspension in $2 \mathrm{~mm}$-dithiothreitol and sedimentation at $32000 \mathrm{~g}$. The cell paste was stored under liquid nitrogen.

Cell-free extract. In general, cell paste and potassium phosphate buffer $(0.02 \mathrm{M}, \mathrm{pH} 6.5)$ were mixed $\mathrm{I}: \mathrm{I}(\mathrm{w} / \mathrm{w})$ and disrupted ultrasonically (Soniprobe, type I130A, Dawe Instruments, London) for three $\mathrm{I} 5 \mathrm{~s}$ periods separated by I min intervals for cooling. Cell-free extract was the supernatant fluid obtained after centrifuging $\left(0^{\circ} \mathrm{C}, 32000 \mathrm{~g}, \mathrm{I} \mathrm{h}\right)$. Protein was determined according to McGrath (1972).

Except where stipulated otherwise, the concentrations of reactants were as given in the legend for Fig. I. The $\mathrm{pH}$ optimum of the enzyme was determined with sodium acetate, potassium phosphate, Tris/ $\mathrm{HCl}$ and imidazole/ $\mathrm{HCl}$ buffers to a final concentration of $17 \mathrm{mM}$. The $\mathrm{pH}$ of individual reaction mixtures was measured.

Biochemicals were obtained from Boehringer.

\section{RESULTS AND DISCUSSION}

The cell-free extract contained NADH oxidase activity. Oxidation of NADH by pyruvate could therefore only be detected if the amount of extract used in the assay was small (IO to $20 \mu \mathrm{g}$ protein). Lactate dehydrogenase activity was markedly increased by the addition of fructose I,6-diphosphate (Fig. I). The concentration of fructose 1,6-diphosphate for half 


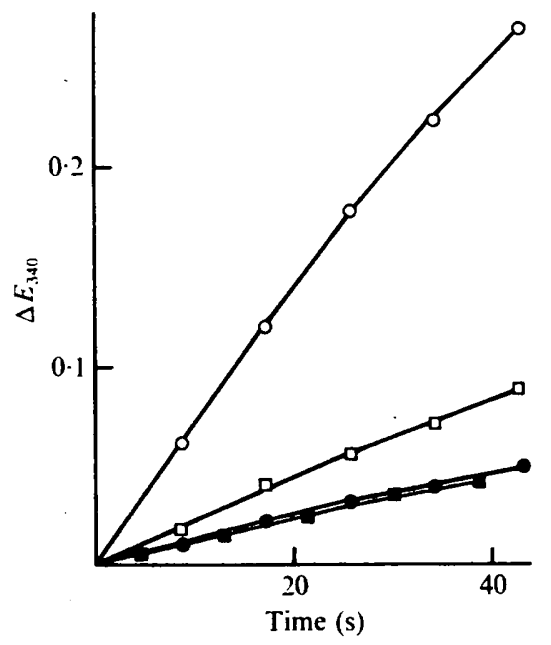

Fig. I. Activation of lactate dehydrogenase of $\boldsymbol{B}$. fibrisolvens by fructose 1,6-diphosphate. Complete reaction mixtures contained: Tris/ $\mathrm{HCl}$ buffer, $16.7 \mathrm{mM}(\mathrm{pH} 7$, final $\mathrm{pH}$ of mixtures was 6.9); sodium pyruvate, 33.3 mM; NADH, $0.17 \mathrm{~mm}$; fructose 1,6-diphosphate, $0.67 \mathrm{~mm}$; cell-free extract, $20 \mu \mathrm{g}$ protein. Total volume, $3 \mathrm{ml}$; incubation temperature, $30^{\circ} \mathrm{C}$. Extinction at $340 \mathrm{~nm}$ ( $10 \mathrm{~mm}$ light path) was read against air. $O$, Complete reaction mixture; $\square$, fructose 1,6 -diphosphate absent; , pyruvate absent; $\square$, fructose 1,6 -diphosphate and pyruvate absent.

maximum activity was $0.23 \mathrm{~mm}$ which compares with $0.3 \mathrm{~mm}$ for fructose $\mathrm{I}, 6$-diphosphatedependent lactate dehydrogenase in crude extracts of $L$. casei (de Vries et al., I970). Holland \& Pritchard (1975) obtained a much lower figure (0.002 mM at optimum $\mathrm{pH}$ ) for purified enzyme from $L$. casei. Hence the figure of $0.23 \mathrm{~mm}$ (at optimum $\mathrm{pH}$ ) for lactate dehydrogenase of $B$. fibrisolvens may also be too high.

The crude enzyme preparations did not require added phosphate for activation. Extracts of $B$. fibrisolvens prepared in deionized water, diluted in water and adjusted to $\mathrm{pH} 6.8$ with $\mathrm{KOH}$ lost $40 \%$ of their activity in $4.5 \mathrm{~h}$ at $0{ }^{\circ} \mathrm{C}$. Similar extracts diluted in potassium phosphate buffer $(0.0 \mathrm{I}$ or $0.05 \mathrm{M}, \mathrm{pH} 6.8)$ had the same initial activity but lost less ( 25 and $16 \%$ ). An extract diluted in Tris/ $\mathrm{HCl}(\mathrm{pH} \mathrm{6.9}, 0.01 \mathrm{M}$ ) also had the same initial activity, but lost activity three to four times as fast as one prepared with phosphate buffer (pH 6.5, $0.01 \mathrm{M})$. The enzyme in B. fibrisolvens thus appears to differ from that of Streptococcus bovis (Wolin, 1964) which required phosphate in addition to fructose 1,6 -diphosphate for activation. It also differs from that of Streptococcus cremoris (Jonas, Anders \& Jago, 1972) which showed inhibition of fructose 1,6 -diphosphate activation by phosphate.

The pH optimum in both phosphate and Tris buffer was 6.8 to 6.9 , but it was 7.0 in imidazole buffer. Within the $\mathrm{pH}$ range 5 to $8, \mathrm{Mn}^{2+}$ (I $\mathrm{mM}$ ) caused slight inhibition, whereas the enzyme of $L$. casei is stimulated (Holland \& Pritchard, 1975).

The conversion of lactate to pyruvate was also stimulated by fructose 1,6 -diphosphate but in this case, unlike the reverse reaction, no activity was observed unless dithiothreitol (at I $\mathrm{mM}$ ) was added. Even when stringent anaerobic precautions were observed in the preparation of the extract and reaction mixtures there was a delay, usually of about 2 min, before reaction started. The $\mathrm{pH}$ optimum for this reaction was $8 \cdot 2$ in Tris buffer. Activity was less than $5 \%$ of that for the conversion of pyruvate to lactate. Both D- and L-lactate could serve as substrates with initial reaction rates in the order $\mathrm{D}>\mathrm{DL}>\mathrm{L}$. It was not determined whether both D- and L-specific enzymes occur or whether a racemase is present. 
Most of the lactate dehydrogenases that depend in some way on activation by fructose I,6-diphosphate belong to either the Streptococcaceae or the Actinomycetaceae suggesting that an evolutionary link might exist between these groups (Eisenberg, Elchisak \& Rudd, 1976). However, B. fibrisolvens does not belong to either of these groups, its affiliation being uncertain (Bergey's Manual of Determinative Bacteriology, 1974).

Since the conversion of pyruvate to lactate is energetically less favourable than conversion to acetate or butyrate, the control of lactate dehydrogenase by the fructose 1,6 -diphosphate levels within the cell may provide a useful system for regulating the normal pathway of glucose catabolism, and it is possible that it may be more widespread than previously recognized.

I wish to thank Dr H. M. Schwartz for advice and interest.

\section{REFERENCES}

Bergey's Manual of Determanative Bacteriology, 8th edn (1974). Edited by R. E. Buchanan and N. E Gibbons. Baltimore: Williams \& Wilkins Co.

EISENBERG, R. J., ElChISAK, M. \& RUDD, J. (1976). Regulation of lactate dehydrogenase activity in Rothia dentocariosa by fructose 1, 6-diphosphate and adenosine 5-triphosphate. Journal of Bacteriology 126, 1344-1346.

VAN GYLSWYK, N. O. (1976). Some aspects of the metabolism of Butyrivibrio fibrisolvens. Journal of General Microbiology 97, 105-III.

Holland R. \& Pritchard, G. G. (1975). Regulation of the L-lactate dehydrogenase from Lactobacillus casei by fructose-1,6-diphosphate and metal ions. Journal of Bacteriology 121, 777-784.

JoNAS, H. A., ANDERs, R. F. \& JAGO, G. R. (1972). Factoris affecting the activity of the lactate dehydrogenase of Streptococcus cremoris. Journal of Bacteriology III, 397-403.

JOYNER, A. E. \& BALDWIN, R. L. (1966). Enzymatic studies of pure cultures of rumen microorganisms. Journal of Bacteriology 92, $1321-1330$.

KISTNER, A. \& Kotzé, J. P. (1973). Enzymes of intermediary metabolism of Butyrivibrio fibrisolvens and Ruminococcus albus grown under glucose limitation. Canadian Journal of Microbiology 19, I 1 I9-I 27.

MCGrATH, R. (1972). Protein measurement by ninhydrin determination of amino acids released by alkaline hydrolysis. Analytical Biochemistry 49, 95-102.

de VRIES, W., KapteiJn, W. M. C., van Der Beek, E. G. \& STouthamer, A. H. (1970). Molar growth yields and fermentation balances of Lactobacillus casei $\mathrm{L} 3$ in batch cultures and in continuous cultures. Journal of General Microbiology 63, 333-345.

Wolin, M. J. (1964). Fructose-I,6-diphosphate requirement of streptococcal lactic dehydrogenases. Science I46, 775-777. 